\title{
Germline Mutation in the von Hippel-Lindau Gene in Kuwait
}

\author{
A Clinical and Molecular Study
}

\author{
Suad M. AlFadhli ${ }^{a}$ Bader Mohammed $^{\mathrm{b}}$ Ahmid Yassin $^{\mathrm{b}}$ \\ ${ }^{a}$ Department of Medical Laboratory Sciences, Faculty of Allied Health Sciences, and ${ }^{\text {b}}$ Faculty of Graduate Studies, \\ Kuwait University, Kuwait
}

\section{Key Words}

von Hippel-Lindau gene $\cdot$ Polymerase chain reaction single-strand conformation polymorphism $\cdot$ Kuwait

\begin{abstract}
Objectives: We aimed to investigate germline mutation in another extended von Hippel-Lindau (VHL) family in Kuwait with Arabian and Persian genetic admixture. Materials and Method: Polymerase chain reaction (PCR) followed by single-strand conformation polymorphism (SSCP) and direct sequencing of the PCR amplicons, that showed clear band shift, were used to screen the $V H L$ gene in the index patient, 20 members of her family and 55 healthy controls of matching ethnicity. Result: The clinical history of all patients revealed multiple hemangioblastomas in various organs without pheochromocytomas. SSCP showed a clear band shift in 2 PCR amplicons, which were then sequenced. One was in the promoter region revealing a polymorphic site (A-123G) found as heterozygous in $40 \%$ of the healthy control subjects of the same ethnicity. The second band shift was in exon 2 seen in all clinically diagnosed VHL cases but not in the healthy members of the family or the screened healthy population. Direct sequencing revealed it was a heterozygous missense mutation G564T (Trp117Cys). Tracking the mutation in the family pedigree showed its origin from the Persian side. Conclusion: This is a second missense G564T mutation in another VHL patient from Kuwait that will help expand our knowledge of the $V H L$ gene mutation spectrum in this region of the world.

Copyright $\odot 2008$ S. Karger AG, Basel
\end{abstract}

\section{Introduction}

von Hippel-Lindau (VHL) disease (MIM No. 193300) is a dominantly inherited cancer syndrome characterized by predisposition to multiple tumors of the eyes and central nervous system (hemangioblastomas), kidneys (renal cell carcinoma), adrenal chromaffin cells (pheochromocytoma) and other organs [1]. Hemangioblastomas are benign cystic tumors that appear as an overproliferation of blood vessels with a neoplastic stromal component, but due to their location in the eyes, brain stem or spine they cause considerable morbidity [2]. Pheochromocytoma, renal cell carcinoma and pancreatic tumors can all be malignant and therefore early detection is vital.

The VHL gene (GenBank accession No. AF010238.1) was isolated in 1993 and consists of 3 exons encoding a 4.7-kb mRNA, covering less than $20 \mathrm{~kb}$ of genomic DNA on chromosome 3p25-p26 [3]. Mutations or deletions in the VHL gene have been identified in the germline of nearly all tested individuals with VHL disease. The mutation spectrum is heterogeneous with mutations scattered throughout most of the VHL gene. Although some recurrent mutations have been reported, most families have their own unique germline mutation [4-6]. The age of onset of VHL disease is variable and depends on the expression of the disease within the individual [7]. As an intensive screening program can greatly increase the number of known affected individuals in a family, carriers of the mutated VHL gene can be monitored closely and given appropriate treatment.

\section{KARGER}

Fax +41613061234 E-Mail karger@karger.ch www.karger.com (c) 2008 S. Karger AG, Basel

$1011-7571 / 08 / 0175-0395 \$ 24.50 / 0$

Accessible online at:

www.karger.com/mpp
Dr. Suad AlFadhli

Department of Medical Laboratory Sciences

Faculty of Allied Health Sciences, Kuwait University, PO Box 31470

Sulaibekhat 90805 (Kuwait)

Tel. +965944 5422, Fax +965 498 3835, E-Mail Suadq8@yahoo.com 
Fig. 1. Multigenerational family pedigree representing 37 members with the index patient (III-9/arrow) and the Persian grandmother I-1.

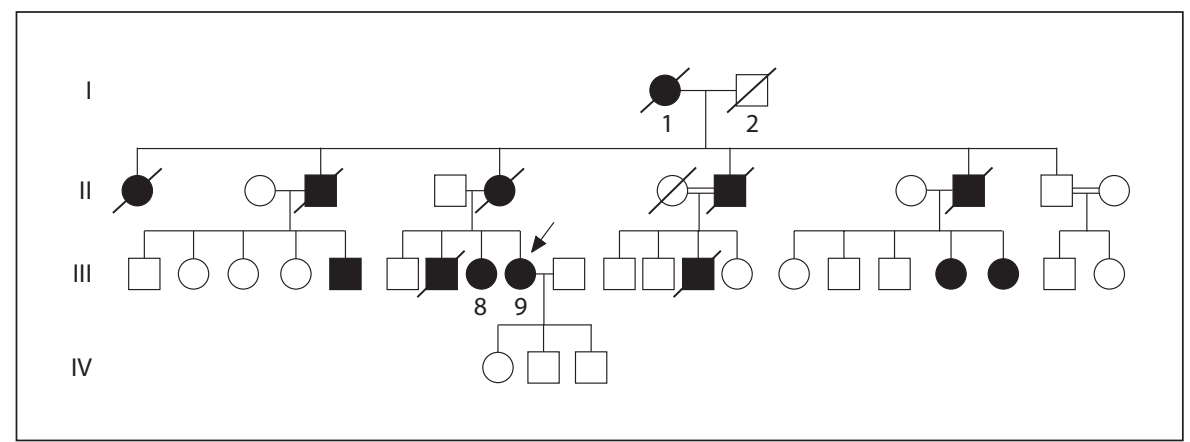

In Kuwait, a family with VHL was identified earlier with a novel mutation in the splice donor site of the first intron [8]. The mutation was identified as IVS $1+$ $1 \mathrm{G} \rightarrow \mathrm{T}$. Here we report the mutation in the VHL gene in another multigenerational extended Kuwaiti family with Arabian and Persian genetic admixture diagnosed as having VHL.

\section{Materials and Methods}

\section{Patient Samples and Clinical History}

The study was approved by the Kuwait University/Health Science Center ethics committee in Kuwait. After informed consent, a 4-generational Kuwaiti family with Arabian and Persian genetic admixture was recruited in this study. All clinical data of the index patient were obtained from the patient's record [9]. Thirteen members of the family had been clinically diagnosed as having VHL and had gone through several surgeries in Ireland, the UK and the USA [9]. The family pedigree was constructed (fig. 1) based on the family medical history and the available reports. Individuals I-1, II-1, II-3, II-5, II-7, II-9, III-7 and III-13 had been clinically diagnosed as having VHL disease and had expired at early ages between 35 and 45 years. Individuals III-8, III-9, III-18 and III-19 had been clinically diagnosed as having VHL disease and they are receiving a very intensive medical care. The rest of the family members were physically healthy and were confirmed in our molecular analysis not to carry the mutated VHL gene.

The index patient, III-9, presented with a history of VHL syndrome and multiple hemangioblastomas. The clinical history of all other patients revealed multiple hemangioblastomas in various organs and renal cell carcinoma without pheochromocytomas. Only one affected member of the family (III-8) had been diagnosed as having a bladder tumor, considered rare in VHL cases, and a brain tumor. Patient III-9 (the index patient) had undergone multiple surgeries because of tumors involving the cerebellum, cervical spine, lumbar spine, multiple abdominal and pelvic organs and the retina. The tumor had been demonstrated on angiography as very extensive and vascular. The patient had had a partial nephrectomy, adrenalectomy, distal pancreatomy for involvement of the tail of the pancreas with a hemangioblastoma and a left salpingoophorectomy. Most recently, the patient was found to have a metastatic renal cell cancer to $L_{5}$ that developed into a progressively enlarging tumor destroying the left $\mathrm{L}_{5}$ vertebral body with progressive left-sided $\mathrm{L}_{5}$ and $\mathrm{S}_{1}$ radiculopathy. The tumor was described as being very necrotic and very highly vascular and therefore, was devascularized prior to surgery. The bone surrounding the tumor was not invaded but was mainly eroded by the tumor mass. Because the patient did not have any known history of hypertension and the right adrenal had been removed, it was concluded the VHL disease was not associated with a pheochromocytoma.

\section{DNA Extraction and Polymerase Chain Reaction}

A sample of $3 \mathrm{ml}$ of whole blood was drawn into a vacutainer containing EDTA from the index patient, members of her family and 55 healthy controls of matching ethnicity after obtaining informed consent. Genomic DNA was extracted from the patient and control blood samples immediately using the conventional method of proteinase $\mathrm{K}$ digestion and phenol-chloroform extraction. Five sets of primers covering the 3 exons and the exon-intron boundaries of the VHL gene were used [8]. Each polymerase chain reaction (PCR) for all exons and exon-intron boundaries was composed of $100 \mathrm{ng}$ of genomic DNA, $1 \times$ PCR buffer (Perkin Elmer, USA), 10 pmol of each PCR primer, $25 \mu \mathrm{M}$ of deoxynucleoside triphosphate, $2.0 \mathrm{mM}$ of $\mathrm{MgCl}_{2}$ and $0.25 \mathrm{U}$ of Taq polymerase (Perkin Elmer) in a total volume of $25 \mu$ l. The PCRs were performed on a DNA thermal cycler (9700 Perkin Elmer) using the following sequence: denaturation step at $95^{\circ} \mathrm{C}$ for $3 \mathrm{~min}$; then 35 cycles of denaturation at $95^{\circ} \mathrm{C}$ for $1 \mathrm{~min}$, annealing at $58^{\circ} \mathrm{C}$ for $1 \mathrm{~min}$ and elongation at $72^{\circ} \mathrm{C}$ for $1 \mathrm{~min}$; then a final step of $10 \mathrm{~min}$ at $72{ }^{\circ} \mathrm{C}$. A $10-\mu$ l portion of the PCR product was checked on $1 \%$ agarose.

\section{Single-Strand Conformation Polymorphism}

Single-strand conformation polymorphism (SSCP) analysis was performed by mixing $3 \mu \mathrm{l}$ of the PCR reactant with $3 \mu \mathrm{l}$ of stop solution (10 $\mathrm{mM}$ of $\mathrm{NaOH}, 95 \%$ formamide, $0.05 \%$ xylene cyanol, $0.05 \%$ bromophenol blue), heated to $95^{\circ} \mathrm{C}$ for $5 \mathrm{~min}$ and chilled on ice for $6 \mathrm{~min}$. The entire mixture was then loaded onto a horizontal nondenaturing $0.9 \mathrm{~mm} \times 50 \mathrm{~cm} \times 21 \mathrm{~cm}$ gel that was $60 \mathrm{ml}$ of $0.5 \times$ MDE gel $(2 \times$ Mutation Detection Enhancement) with $5 \%$ glycerol, $48 \mu$ l of tetramethylethylenediamine and $380 \mu \mathrm{l}$ of $20 \%(\mathrm{w} / \mathrm{v})$ ammonium persulfate. The gel was run at $250 \mathrm{~V}$ and $45 \mathrm{~W}$ overnight at room temperature with $1 \times$ AccuGene TBE ( $0.89 \mathrm{M}$ of Tris/Borate, $0.02 \mathrm{M}$ of EDTA, $\mathrm{pH}=8.3)$ run- 
ning buffer. The resulting bands were visualized by silver nitrate staining.

\section{Silver Nitrate Staining}

The gels were fixed in 2 changes of fixation solution (10\% ethanol, $0.5 \%$ acetic acid) each for 5 min with gentle shaking. They were stained for $15 \mathrm{~min}$ in freshly prepared $0.1 \%$ silver nitrate and rinsed briefly with distilled water. The gels were then incubated in developing solution ( $1.5 \% \mathrm{NaOH}, 0.1 \%$ formaldehyde) for 30 $\mathrm{min}$. Finally the gels were treated with $0.75 \% \mathrm{Na}_{2} \mathrm{CO}_{3}$ solution for $10 \mathrm{~min}$, sealed in a plastic bag and photographed.

\section{DNA Sequencing}

PCR amplicons that showed a clear SSCP shift were subjected to sequencing. In a total volume of $25 \mu \mathrm{l}, 1 \mu \mathrm{l}$ of the cleaned PCR product was mixed with $3.2 \mu \mathrm{l}(1 \mathrm{pM})$ of either the forward or the reverse primer, and $4 \mu \mathrm{l}$ of the dye terminator ready sequence reaction mix (Prism TM Ready Reaction DyeDeoxy TM Terminator Cycle Sequencing Kit, ABI) and $4 \mu$ l of BigDye terminator v3.1 $5 \times$ sequencing buffer. The sequencing reaction was then carried out in a 9700 thermocycler programmed to 25 cycles of $96^{\circ} \mathrm{C}$ for $10 \mathrm{~min}, 50^{\circ} \mathrm{C}$ for $5 \mathrm{~s}$ and $60^{\circ} \mathrm{C}$ for $4 \mathrm{~min}$. The sequencing reaction was ethanol precipitated and $25 \mu \mathrm{l}$ of deionized formamide was added to the pellet, mixed, heated for $2 \mathrm{~min}$ at $95^{\circ} \mathrm{C}$, kept on ice till the sequencing run on an automated DNA sequencer (ABI3100, Applied Biosystems, USA).

\section{Results}

Of the 13 members of the family clinically diagnosed as having VHL, one member, I-1, had Persian background and her medical history revealed that she was the carrier for the mutated VHL gene which 5 of her 6 offspring inherited (fig. 1). The age of onset for all patients varied from as young as 16 to 40 years. The index patient presented to us for molecular investigation of the VHL gene mutation.

The SSCP showed a clear band shift in 2 amplified fragments representing the promoter region and exon 2. Sequencing both fragments revealed a single-nucleotide polymorphic site in the promoter region at position A-123G (fig. 2a) that was found in the heterozygous state in $40 \%$ of the 55 healthy controls with the same ethnic background.

The second SSCP band shift revealed the pathogenic mutation in exon 2 that was a heterozygous missense mutation G563T (Trp117Cys) (fig. 2b). This mutation was found in the index patient as well as all relatives with clinical diagnoses but in none of the healthy members of the family or in the 55 healthy control subjects.

The rest of the VHL gene of the index patient was completely sequenced later to confirm that the identified mutated site was the only cause of the disease.

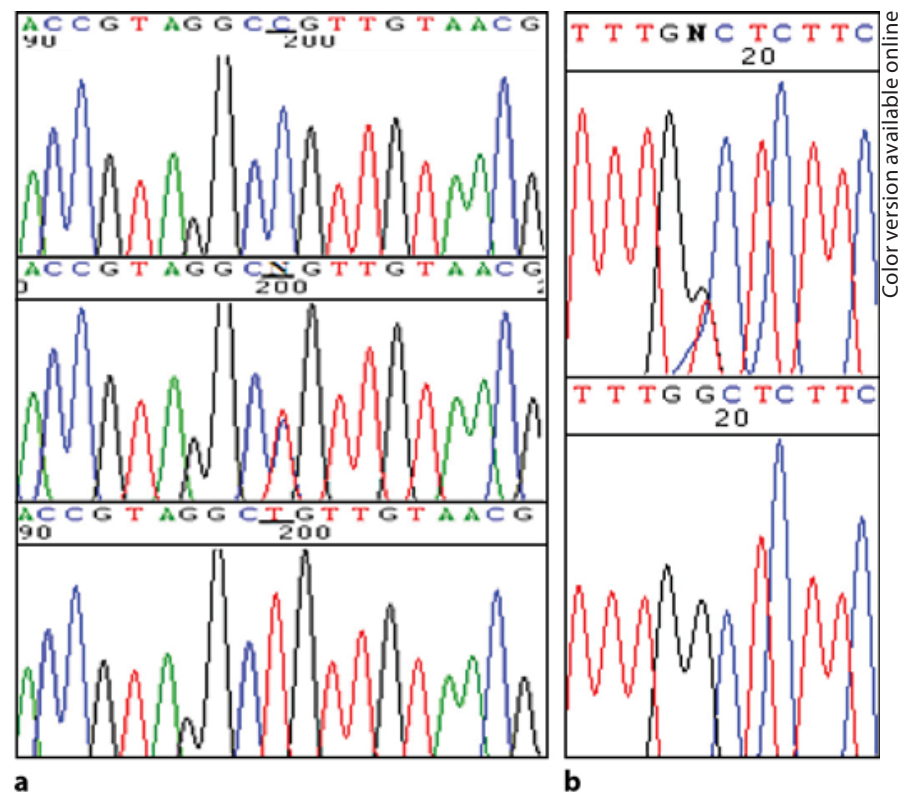

Fig. 2. a The homo- and heterozygous sequence of the singlenucleotide polymorphic site -123 G/A (using reverse primers). b The mutation site at G564T in exon 2 (using forward primers).

\section{Discussion}

The identification of the VHL gene has enabled molecular diagnosis in affected individuals and at-risk relatives to find gene carriers. Relatives who are shown not to carry the mutated gene can be reassured and excluded from screening protocols, while affected individuals and unaffected gene carriers require life-long surveillance to enable the detection of tumors at a presymptomatic stage. The early detection and treatment of VHL complications, particularly renal cell carcinoma and retinal and cerebellar hemangioblastomas, can reduce morbidity and mortality from VHL disease. Thus, unlike in some other genetic diseases, there are clear clinical benefits from predictive testing in VHL disease, and the uptake rate for genetic testing in affected families is high (>85\%) [1012].

We present here a second VHL mutation found in an extended multigenerational Kuwaiti family with Arabian and Persian genetic admixture. The mutation was carried to Kuwait by the great grandmother with Persian ancestry (member I-1 from the pedigree, fig. 1). The first VHL gene mutation in Kuwait was detected in a Kuwaiti family with a novel germline mutation in the splice donor site of the first intron IVS $1-1 \mathrm{G} \rightarrow \mathrm{T}$ [8]. However, the family investigated here had a heterozygous missense muta- 
tion in exon 2 at position G564T (Trp117Cys). This mutation had previously been identified by Chen et al. [4] when they screened 114 Northern American families and further reported by other investigators [6, 13-15].

The G564T mutation is one of a few identified in exon 2 as most of the VHL mutations are clustered at the $3^{\prime}$ end of exon 1 and the $5^{\prime}$ end of exon 3. The G564T mutation replaces an amino acid: tryptophan, containing an indole ring with an amino acid: cysteine, capable of forming disulfide bonds from a different class (Trp117Cys), which was the case with all missense mutations identified by Chen et al. [4]. It appears that tryptophan acid has a critical role in VHL protein function as tumor suppressor.

Ruiz-Llorente et al. [15] in addition to investigating the relevance of different amino acid changes in the VHL phenotype have also analyzed the genotype-phenotype correlations using structural analysis to assess protein stability and complexes. They observed an association between clear cell renal carcinoma development and the relatively high loss of structural stability (high $\Delta \Delta \mathrm{G}$ values) in protein VHL missense mutants, where $\Delta \Delta \mathrm{G}$ is the free energy difference between the wild-type and the mutant protein. The estimated $\Delta \Delta \mathrm{G}$ value for Trp117Cys is $5.64[16]$.

All members of the presented family had clear cell renal carcinomas that were the main cause of mortality, in addition to angiomas and hemangioblastomas. All affected members of the family, however, lacked any evidence of pheochromocytoma, leading to the categorization of this family as VHL type 1 despite the presence of a missense mutation rather than a deletion or premature truncation mutation [16]. In the study done by Chen et al. [4] 99\% of all individuals with VHL who developed pheochromocytomas had missense mutations including the G564T mutation. Based on this genotype-phenotype correlation Chen et al. concluded that individuals with missense mutations are more likely to develop pheochromocytoma than those with deletions or protein-truncating mutations. This finding contrasts with that reported by Olschwang et al. [6] for French VHL patients with G564T mutation. These patients did not develop pheochromocytomas similar to our case. However, age-dependent penetrance could be one of the reasons for not developing pheochromocytoma. In our present study the proband was 40 years old and until this age the patient did not develop any signs of pheochromocytoma. Very recent work by Ong et al. [17], comparing the type of mutation and the age of onset of the clinical manifestations including pheochromocytoma, showed that the mean age at diagnosis of pheochromocytoma was earlier in those with surface missense amino acid substitutions $(21.69 \pm 10.5$ years $)$ than in those with deep missense mutations $(27 \pm 9.7$ years, $p=0.0166)$. Therefore, it is still possible that the patients in this Kuwaiti family could develop pheochromocytoma later in life.

Another probability is that the development of pheochromocytomas could be a product of a multigene system and not necessarily solely due to the mutation in the VHL gene. Variation in the cyclin D1 gene has been proposed as one genetic modifier affecting the progression to pheochromocytoma $[18,19]$. We hope that further advances in understanding the VHL genotype-phenotype correlation might eventually enable the development of specific therapies for the prevention or treatment of VHL tumors.

\section{Conclusion}

This is a second missense G564T mutation in another VHL patient from Kuwait that will help expand our knowledge of the VHL gene mutation spectrum in this region of the world.

\section{Acknowledgments}

This work was partially supported by Kuwait University, research administration grant No. YN01/05. We are grateful to all members of the participating family for their cooperation.

References

Friedrich CA: Von Hippel-Lindau syn-
drome: a pleomorphic condition. Cancer
1999;86:2478-2482.
Richard S, Campello C, Taillandier L, Parker
F, Resche F, French VHL Study Group:
Haemangioblastoma of the central nervous
system in von Hippel-Lindau disease. J In-
tern Med 1998;243:547-553.
3 Phipps ME, Maher ER, Affara NA, Latif F,
Leversha MA, Ferguson-Smith ME, Naka-
mura Y, Lerman M, Zbar B, Ferguson-Smith
MA: Physical mapping of chromosome
3p25-p26 by fluorescence in situ hybridisa-
tion (FISH). Hum Genet 1993;92:18-22.
Chen F, Kishida T, Yao M, Hustad T, Glavac
D, Dean M, Gnarra JR, Green J, Hsia E,
Lamiell J, Li H, Wei MH, Schmidt L, Tory K,
Kuzmin I, Stackhouse T, Latif F, Linehan
WM, Lerman M, Zbar B: Germline muta-
tions in the von Hippel-Lindau disease tu-
mor suppressor gene: correlations with phe-
notype. Hum Mutat 1995;5:66-75.

AlFadhli/Mohammed/Yassin 
5 Hes F, Zewald R, Peeters T, Sijmons R, Links T, Verheij J, Matthijs G, Leguis E, Mortier G, Torren K, Rosman M, Lips C, Pearson P, Luijt $\mathrm{R}$ : Genotype-phenotype correlations in families with deletions in the von Hippel-Lindau (VHL) gene. Hum Genet 2000;106:425-431.

-6 Olschwang S, Richard S, Boisson C, Giraud S, Laurent-Puig P, Resche F, Thomas G: Germline mutation profile of the VHL gene in von Hippel-Lindau disease and in sporadic hemangioblastoma. Hum Mut 1998;12: 424-430.

7 Maddock IR, Moran A, Maher ER, Teare MD, Norman A, Payne SJ, Whitehouse R, Dodd C, Lavin M, Hartley N, Super M, Evans DG: A genetic register for von Hippel-Lindau disease. J Med Genet 1996;33:120-127.

$\checkmark 8$ Alfadhli S, Salim M, Al-Awadi S: A novel germline mutation in the von Hippel-Lindau gene in patients in Kuwait. Med Princ Pract 2004;13:312-315.

9 Long DM, Gokaslan ZL, Samdani AF: Operative report. Baltimore, John Hopkins Hospital, 2004, history No 0-311-29-90.

$\checkmark 10$ Evans DG, Maher ER, Macleod R, Davies DR, Craufurd D: Uptake of genetic testing for cancer predisposition. J Med Genet 1997; 34:746-748.
11 Levy M, Richard S: Attitudes of von HippelLindau disease patients towards presymptomatic genetic diagnosis in children and prenatal diagnosis. J Med Genet 2000;37: 476-478.

12 Zbar B, Kishida T, Chen F, Schmidt L, Maher ER, Richards FM, Crossey PA, Webster AR, Affara NA, Ferguson-Smith MA, Brauch H, Glavac D, Neumann HPH, Tisherman S, Mulvihill JJ, Gross DJ, Shuin T, Whaley J, Seizinger B, Kley N, Olschwang S, Boisson C, Richard S, Lips CHM, Linehan WM, Lerman M: Germline mutations in the Von HippelLindau disease (VHL) gene in families from North America, Europe, and Japan. Hum Mutat 1996;8:348-357.

13 Dollfus H, Massin P, Taupin P, Nemeth C, Amara S, Giraud S, Beroud C, Dureau P, Gaudric A, Landais P, Richard S: Retinal hemangioblastoma in von Hippel-Lindau disease: a clinical and molecular study. Invest Ophthalmol Vis Sci 2002;43:30673074.

14 Gallou C, Chauveau D, Richard S, Joly D, Giraud S, Olschwang S, Martin N, Saquet C, Chrétien Y, Méjean A, Correas JM, Benoît G, Colombeau P, Grünfeld JP, Junien C, Béroud $\mathrm{C}$ : Genotype-phenotype correlation in von Hippel-Lindau families with renal lesions. Hum Mutat 2004;24:215-224.
15 Ruiz-Llorente S, Bravo J, Cebrián A, Cascón A, Pollan M, Tellería D: Genetic characterization and structural analysis of VHL Spanish families to define genotype-phenotype correlations. Hum Mutat 2004;23:160-169.

16 Friedrich CA: Genotype-phenotype correlation in von Hippel-Lindau syndrome. Hum Mol Genet 2001;10:763-767.

17 Ong KR, Woodward ER, Killick P, Lim C, Macdonald F, Maher ER: Genotype-phenotype correlations in von Hippel-Lindau disease. Hum Mutat 2007;28:143-149.

18 Webster AR, Richards FM, MacRonald FE, Moore AT, Maher ER: An analysis of phenotypic variation in the familial cancer syndrome von Hippel-Lindau disease: evidence for modifier effects. Am J Hum Genet 1998; 63:1025-1035.

19 Zatyka M, da Silva NF, Clifford SC, Morris MR, Wiesener MS, Eckardt KU, Houlston RS, Richards FM, Latif F, Maher ER: Identification of cyclin D1 and other novel targets for the von Hippel-Lindau tumor suppressor gene by expression array analysis and investigation of cyclin D1 genotype as a modifier in von Hippel-Lindau disease. Cancer Res 2002;62:3803-3811. 